\title{
Public Spaces and Private Spaces Open to the Public: Spatial Planning and Development Using Urban Design Guidelines
}

\author{
Liljana Jankovič Grobelšek*
}

Department of Spatial Planning, City Administration, City of Ljubljana, Slovenia

\begin{abstract}
The continuing growth of urban populations has intensified the need for cities to provide conditions for a healthy and creative way of life, work, and leisure activities. From the aspect of spatial planning in cities, the key is to have a public space network of sufficient scope and quality. "In addition to public space, which is public in terms of ownership and use, private space open to the public is important" [1], i.e. space that is "privately owned, but in public use. It comprises parts of private structures and their external areas" [1], such as green areas, squares, atria, shopping centre arcades, movie theatres, and similar. The development of network of private space open to the public in Slovenian cities was not planned, but was driven by owners' profit motivations. The study findings presented in this paper show that private space open to the public could complement and improve the city's public space network to a greater extent than now, and that this should be pursued in a planned manner. "By analogy with Slovenian mountain trails that already constitute an extensive network" [1] of private space open to the public outside towns and cities, we suggest the planned development of the network of private space open to the public in urban areas as well. It is connected with, and complementary to, public space. The enforcement of this special spatial planning category can be achieved through urban planning practice, i.e. by using urban design guidelines and by working towards their gradual introduction into legislation.
\end{abstract}

Keywords: Healthy living environment, private space open to the public, public space, public use of space, urban design guidelines

\section{INTRODUCTION}

In planning spatial developments, principles of sustainable development must be taken into account as the fundamental contemporary development paradigm. This involves "development that meets the needs of the present without compromising the ability of future generations to meet their own needs" [2]. Agenda Habitat (Second United Nations Conference on Human Settlements) emphasises solidarity and the importance of carefully managing both natural and living environments. To this end, preserving and keeping a healthy and safe living environment is essential $[3,4]$, and is particularly important in cities, which are home to over one half of the world's population. Environmental problems are growing in today's cities. People living in towns and cities are exposed to many types of pressure, such as an unhealthy living environment and inadequate living and working conditions [5].

The fundamental human rights to a healthy environment are, at the global level, set out in the United Nations declarations [2]. In Europe, residents' rights to a healthy living environment are set out in several documents [6], and at the national level this is laid down by the Constitution of the

*Address correspondence to this author at the Department of Spatial Planning, City Administration, City of Ljubljana, Slovenia; Tel: +38631278516; E-mails: liljana.jankovic@ljubljana.si, liljana.jg@gmail.com
Republic of Slovenia: "Everyone has the right in accordance with the law to a healthy living environment. The state shall promote a healthy living environment" [7]. Hence, the study on the significance of public spaces and private spaces open to the public (hereinafter: PSOPs) was based on findings substantiating the priority of ensuring a healthy living environment. "The measures for increasing the quality of the living environment are mainly implemented as part of the public space network, or space open to the public" [1], i.e. one that enables public use.

The purpose of this paper is to improve "understanding of the role that urban PSOP plays in this regard and to draw attention to the fact that the potentials" [1] of this valuable urban space, which the public may use even though it is privately-owned, have not been realised. "In Slovenia this category of urban space that is private in terms of ownership and usable by the public has not been appropriately defined and is not regulated systematically" [1]. Nevertheless, we assume that in Slovenian towns and cities PSOPs can be provided for as part of applicable legislation, based on professional recommendations and by promoting best practice. This will be demonstrated by the findings of a study on project practice, in which PSOPs (or private spaces that can be placed within this category) are realized or planned" [1].

First, the paper addresses public space and potentials for managing PSOPs, then it presents the findings of the analysis on project practice and the recommendation of urban design 
guidelines for public spaces and privately-owned spaces open to the public, and finally ends with a discussion on the options for development and planning, and conclusions.

\section{PUBLIC SPACE AND PRIVATE SPACE OPEN TO THE PUBLIC}

The central subject matter of the study is public spaces and PSOPs in the modern town or city. Here, we refer to physical public space, and physical PSOP. This concerns in particular the new possibilities for ensuring more accessible and better organised public spaces and PSOPs.

\section{All Participating Public and Private Partners Play an Important Role in Spatial Planning}

In spatial planning, all partners participating in the drafting of pertinent documents, implementing pertinent acts, and in the completion thereof, are important. The partners involve the public sector, the private sector, and the public.

1. The public sector is the municipal and state administration, spatial planners, and the responsible public sector bodies - in the municipal administration, administrative units, the ministries, and at the decision-making level: the government and ministries, municipal councils, and mayors. The public sector manages and coordinates the drafting of spatial planning documents. It manages and guides developers and the public with negotiations and coordination, based on the legislative platform. It owns the public spaces and is, as a rule, the investor in public space developments. The public sector is the authorised guardian of public interests $[8$, 9].

2. The private sector refers to private developers and private land owners who take on the majority of investment initiatives in towns and cities.

3. The public is either general or professional. The general public is the users of urban space, both public and privately-owned space open to the public. The public participates in the drafting of spatial documents in accordance with legislation. The professional community is an important partner which prepares and assesses spatial solutions, and thus guides them. It must stand for the public interest, albeit in a different role than the public sector. The Slovenian Constitution and spatial planning legislation state that in spatial planning private interest must not be harmful to public benefit and that spatial planning activities are in the public interest $[8,9]$.

The quality of spatial solutions depends on town and spatial planners, i.e. the professional community, and the public sector, private developers' engagement, and the general public. It largely depends on the successful cooperation of all partners.

\section{Urban Public Space is Characterised by a Public Part- ner, Public Ownership, and Public Use}

Public space is characterised by public ownership and public use. All partners take part in its organisation, while the public partner and the public are the key partners.
Public space is the central and most important urban space where urban public life takes place, i.e. various types of transport and other urban community facilities. Public space is a place of connections and meetings, and the place of urban public and private interactions. Public space makes possible social gathering, movement, play, recreation, and creativity [10]. Public space in towns and cities (hereinafter also: PS) is generally organised by public partners (state, local communities, public sector, and similar). Public space is freely available to urban users or under certain conditions, such as with closure of public parks at nighttime for safety reasons. Public space provides the venue for various events, social activities, as well as public expression. It is a place of exchange, a place shared on terms of freedom and equality [11].

Urban public space also includes open public space, such as traffic areas and other common areas: squares, parks, green areas, city forests, cemeteries, waterfronts, and similar. Open public spaces are complemented by public structures such as courts, museums, theatres, libraries, markets, public schools, public hospitals, and similar. This includes all the areas and structures that are publicly-owned, in public use, and accessible to everyone. Urban public space is the public space that ensures the conditions for healthy living, public expression, recreation and sports, creativity and play, and similar. To that end, urban public space must be sufficiently extensive, well organised and maintained, as well as freely accessible. It must also be versatile and attractive, encouraging frequent and responsible public use of all public areas. "Public space is the most exposed feature of every town or city, and culture. The capacity of any individual period and the scope of any civilisation is also measured by the public spaces it creates and maintains. Hence both in Ancient Greece and the Roman Empire as well as today, in the era of technologically advanced civilisations, public space was and remains an equally important category" [12].

According to the Construction Act of the Republic of Slovenia, a built public asset is land intended for general use. "A built public asset of national importance is a built public asset belonging to the network of public infrastructure works of national importance and the public area thereon; a built public asset of local importance is a built public asset belonging to the network of public infrastructure works of local importance and the public area thereon. These include any works or parts of works intended for use by all under the same conditions, such as a highway, a street, a square, an arcade or any other public transport area of local importance, a marketplace, a playground, a car park, a cemetery, a park, a green, sports grounds, or a recreation area" [13]. The law stipulates that a public area is an area whose use is intended for all under the same conditions, such as a public highway, a street, a square, a marketplace, a playground, a car park, a cemetery, a park, a green, or a recreation area [13].

However, a review of the status of public spaces in Slovenia reveals that some spaces are well organised, with lively outdoor activities and many visitors (Fig. 1), while others are disorganised and poorly maintained (Fig. 2), or even fenced, closed, and thus not freely available to the public (Fig. 3), while the fundamental characteristic of public 


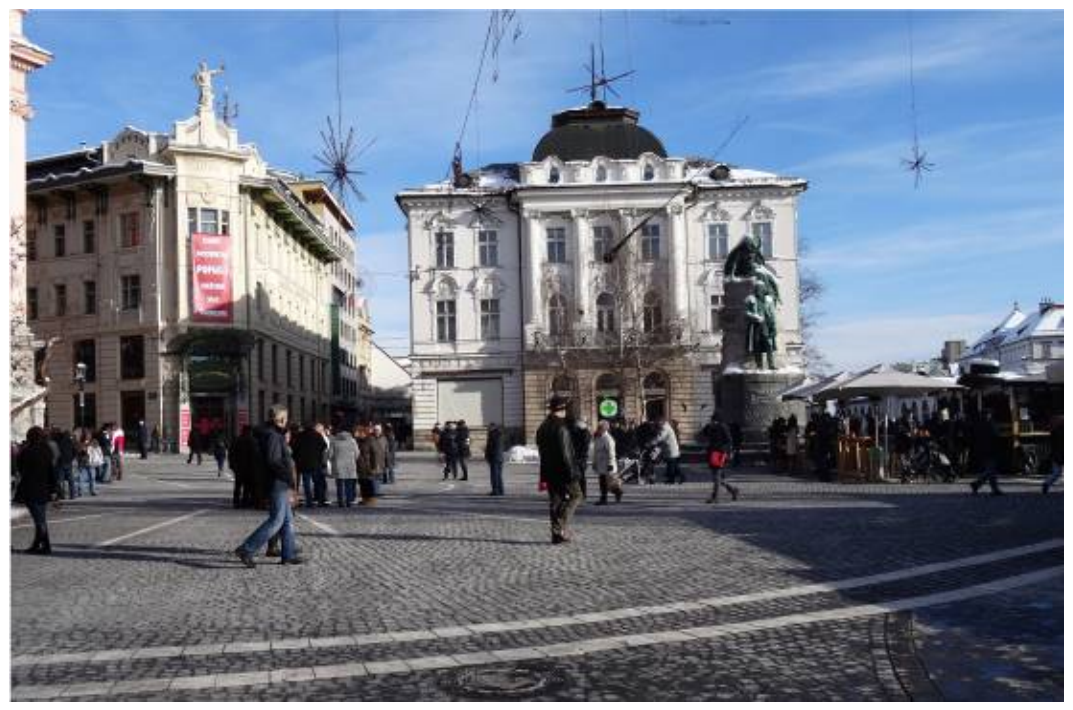

Fig. (1). Prešernov trg (Prešeren Square) in the historical city centre of Ljubljana, the Slovenian capital city, is a successful urban public space - a square featuring a diverse range of outdoor events.

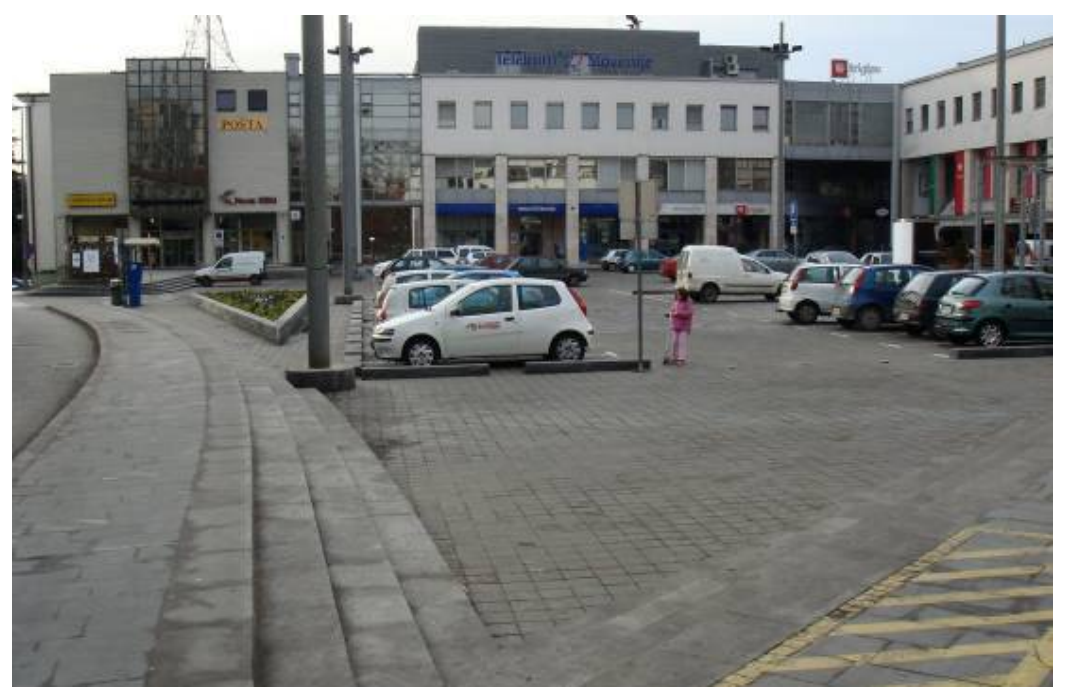

Fig. (2). Novi trg in Novo mesto, Slovenia, lies next to the historical town centre; however, except during occasional events it is occupied by a car park.

space is quite the opposite. A major reason for this is disorganised ownership and poor public land management. It is not rare that parts of roads, parks, cemeteries, and similar, are privately owned. This is due, in particular, to the former social ownership that is still not inadequately regulated, even though the independent Republic of Slovenia, with its new democratic, socioeconomic system, was established over two decades ago. The new system after 1991 created a new relationship to private property, which is a clearly defined constitutional category. Article 33 of the Constitution of the Republic of Slovenia provides for the right to own private property. Limitations to the rights originating in private property shall be permissible by law only [8]. However, the relationship to public ownership has remained equally unregulated. Many land plots in the public domain do not match the actual state on site, their ownership status is not resolved, and similar [14, 15].
Urban public space in Slovenia is frequently poorly defined and disorganised. It is also spatially limited. Material or physical PS is limited to the public domain land plots, i.e. publicly-owned land [16]. According to our study, urban public space constitutes about $20 \%$ of urban areas. By calculating all publicly-owned urban areas (for three cases of Slovenian towns and cities - Ljubljana, Novo mesto, and Črnomelj), we found that in Ljubljana there are about $19 \%$ publicly-owned urban areas, in Novo mesto $22 \%$, and in Crnomelj about $18 \%$. All types of public areas owned by the relevant municipality or the Republic of Slovenia were considered in the calculation. The study also revealed that the scope of urban public areas is not changing significantly. In the organisation of private areas on the one hand, and private ones on the other hand, the percentage of public areas is on average preserved, or even reduced. City administrations with limited public financial and human resources lack the 


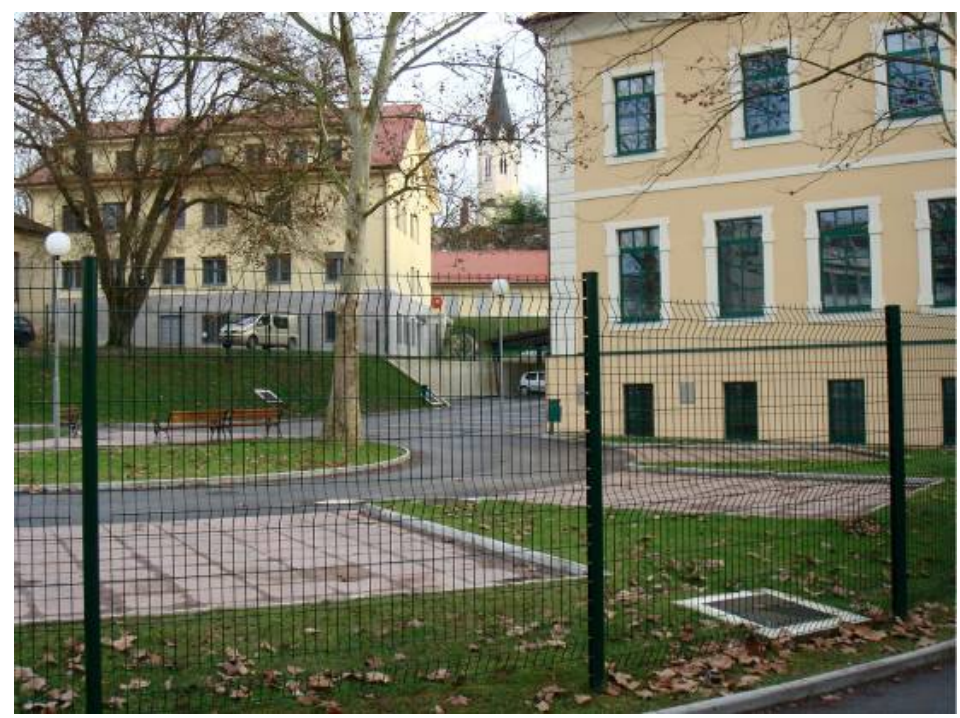

Fig. (3). The Administrative Unit Novo mesto is part of the Republic of Slovenia's state administration. Irrespective of this, its appertaining land is fenced, and car access is prevented by a gate.

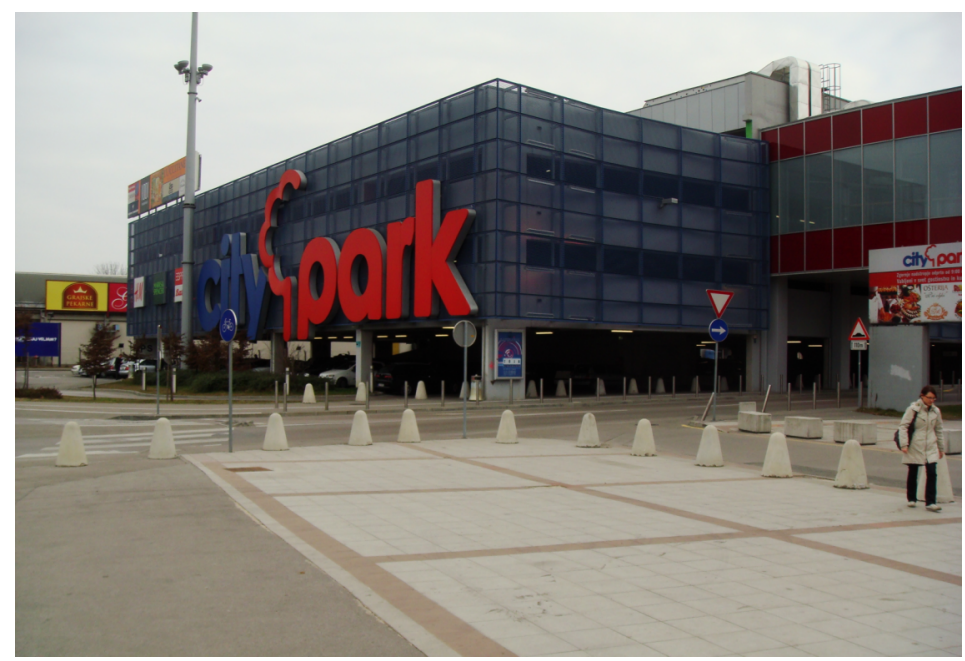

Fig. (4). PSOP in a commercial centre in the suburban part of Ljubljana.

capacity to maintain a large part of public areas. The reasons are to be sought in management problems as well. City administrations must maintain relatively extensive public areas. As they are unable to manage and maintain them, they resort to selling the public areas ${ }^{1}$. However, management problems must not be solved by selling the public domain land. The role of municipal administrations is the provision of the missing financial resources, improved organisation and knowledge to improve the maintenance of public areas.

Noting that the scope of urban public space will no longer increase, we suggest that the scope and organisation of urban space in public use is increased on the account of PSOP [17].

\footnotetext{
${ }^{1}$ Indeed, this solution is the worst of all. The safeguarding of the public domain, i.e. the preservation of the physical PS, is appropriately regulated, as before being sold the status of the public asset must be revoked, which is a rather complex administrative procedure. The revocation of the public asset is confirmed at the municipal council, while evidence needs to be submitted that the public asset in question no longer demonstrates public interest.
}

\section{Urban Private Space Open to the Public is Characterised by A Private Partner and Ownership, and Public Use}

Urban private space open to the public is characterised by private ownership and public use. All partners take part in its organisation, while the public partner and the private owner, i.e. developer, are key.

Private space open to the public (hereinafter also: PSOP) is urban space in private ownership, but open to public use. Although PSOPs are privately owned, it is in their owner's interest that they are used by the public, as this brings economic benefit. PSOPs are developed in connection to activities intended for the public such as shopping centres, movie theatres, service structures and business establishments, and land [18]. PSOP consists of private structures and appertaining external areas, such as plazas, atriums, squares, streets, and green areas at shopping centres (Fig. 4), movie theatres and commercial buildings, as well as passages through private buildings, and similar. PSOPs provide the potential to 
improve the urban public space network and increase the quality of urban living [19]. As in public spaces, this type of private spaces is where city urban life takes place. Of course, these are subject to restrictions, as set by their owners or managers. PSOP is thus provided for in private urban areas in line with 'the owner's interests. However, according to Kayden [19], the city administration can actively promote and guide the organization of the PSOP network, as will be illustrated by a best-practice example from New York".

\section{Urban Private Space is Characterised by a Private Part- ner, Private Ownership, and Private Use}

Urban private space is characterised by private ownership and private use. In its organisation, private and public partners take part only in so far as concerns land use and the establishment of private areas and structures provided for in spatial planning documents, while, in fact, the private partner, i.e. the private owner or developer, is the key actor.

Urban private space (hereinafter also: $\operatorname{PrS}$ ) is urban space in private ownership and private use. PrS is the least relevant to the topic of this paper, and is here considered as all other areas where public use is not possible (Table 1).

\section{Cases of Systematic Management of PSOP}

In Slovenia, PSOPs are defined neither in Slovenian legislation nor in urban planning documents. In fact, they are organised as part of profit-driven private incentives when this is in line with the developer's interest, for example near shops and commercial centres. The latter dedicate most of the PSOP to traffic and commercial areas, and less to squares and playgrounds, and even less to seating areas and parks. We argue that there is unrealised potential for systematically developing more extensive and better organised areas in public use in towns and cities. Some American cities, e.g. New York, set an example [19].

An extensive and well-organised PSOP network outside urban areas is already in place in Slovenia, i.e. the mountain trails system. Free public access to private land via notcultivated land in the hills and mountains is provided for in the Mountain Paths Act [20]. Mountain trails mostly traverse private land; however, in line with the legislation they fall in the category of PSOPs. The Mountain Paths Act [20] defines the roles of each partner:

1. The public partner is the Alpine Association of Slovenia, which has the obligation to manage and maintain the trails.

2. The private sector consists of private landowners who pursuant to the legislation allow the public use of their land which falls into the Slovenian category of PSOP.

3. The public are the users who have the obligation to use them responsibly; only walking, running and climbing on the trails is permitted.

New York, particularly Manhattan, was selected as a reference example of best practice in regulating POPSs, where the systematic development of the so-called privately owned public spaces (POPS) was pioneered in 1961, i.e. when they amended the zoning resolution [19]. Privately-owned public spaces there include plazas and parks "in front of the entrances to business" [17] premises, passageways across private urban blocks, underground railway access, interior squares at commercial centres, restaurants, office buildings, and similar. By expanding POPSs, they systematically increase the urban space accessible by the public, which is particularly important in the densely built-up Manhattan.

In order to achieve this, zoning provides bonuses attracting developers to organise POPS. In exchange for organising POPS, the zoning resolution provides for bonuses such as additional floors and greater building density [21]. Over a few decades, the New York City Department of City Planning encouraged the city to obtain various new privatelyowned public spaces [22]. It also supervises whether the PSOPs are organised and open to the public in line with the building permit provisions. To this end, it developed an extensive electronic database about all privately owned public spaces created [23]. The database includes the key information on PSOPs such as the information from the building permit on the hours that the space is open to the public, the conditions, and facilities (number of benches and seating areas, trees, fountains and similar). At the same time, the City Department of City Planning invites users to report on the conditions on site, thus facilitating control over developer's fulfilment of obligations.

"This increased private investment in POPSs and control over them; moreover, since 1961 the zoning resolution has been continually amended based on experience with its implementation" [17]. In fact, initial experiences with the early POPSs were not the best. Squares did create more open space at the city's street level; however, mostly they failed to satisfy another goal, namely that the space should be useful and pleasant. Developers satisfied the minimum requirements laid out in the building permits, which resulted in poorly designed and inhospitable PSOPs. Some owners raised fences illegally or in other ways restricted public access. The experience with the regulation's implementation in the early years prompted more detailed zoning resolution provisions in terms of allowed floor area ratio, required developments, facilities, etc. Better results soon followed [19].

New York sets an example for other cities. Seattle has also had Privately Owned Public Open Spaces (POPOS) policies since 1966 [24]. Since 1968, the San Francisco Planning and Urban Research Association has encouraged the development of privately-owned public open spaces (POPOS) [25]. In Chicago, the Open Space Section encourages the increase in publicly accessible open space, as public space per capita is scarce, failing to meet national standards. Thus new public spaces and new POPOSs are developed [26]. The development of privately-owned public open spaces (POPOS) or privately owned public spaces (POPS) is also encouraged in other cities such as Pittsburgh [27], Vancouver [28], and Hong Kong [29].

\section{THE PROJECT PRACTICE PILOT STUDY}

The necessity of introducing PSOPs into Slovenian urban design practice and regulations was verified through a 
Table 1. Important terms and abbreviations; ownership and land use [17].

\begin{tabular}{|c|c|c|c|}
\hline Abbreviation & Meaning & Ownership & Use \\
\hline \hline PS & Public Space & $=$ Public Ownership & $=$ Public Use \\
\hline PSOP & Private Space Open to the Public & $=$ Private Ownership & $=$ Public Use \\
\hline PrS & Private Space & = Private Ownership & $=$ Private Use \\
\hline
\end{tabular}

project practice pilot study. "This study was prepared in order to obtain the information on the condition of PSs and the potentials for organising PSOPs" [1]. It was conducted on seven examples of town-planning schemes for urban areas of various sizes (from 3.8 ha to 23.6 ha). Areas with a variety of programming were analysed - five areas with mixed residential, commercial and business activities (mixed use); one industrial area with commercial city-forming activities and services on the margins of the area, and one area for a commercial and business centre [17, 30].

Case study: "Na Kamenju" area, Dolenjske Toplice with mixed residential and business activities (Fig. 5).

In the study we analysed the share (percentage) of PS and PSOP surface areas to be used to draw up the recommended shares of PS and PSOP. "Because in Slovenia PSOP is not defined as a separate spatial category" [17], as has been the case in some foreign cities for decades, we considered as (potential) PSOPs those private spaces in the analysed projects that are open to the public, i.e. are in public use. As it is, these surfaces demonstrate the characteristics of the PSOP category, but they are defined neither in legislation nor in town-planning regulations. Digital project data were used for analysing the surface ratios to accurately calculate the shares. The analysis of seven areas demonstrated that the average share of public areas in the analysed urban areas was $18.2 \%$ of the total surface, while the average share of PSOP was almost $39.8 \%$ of the total surface area. Hence the average share of PrS was only $42 \%$ [17].

The total percentage of all surfaces in public use was rather high and promising, and two things should be noted in this regard.

1. A result of the former socialist socioeconomic system in Slovenia is the relatively high percentage of areas in public use in the areas that were built in the period after World War II until Slovenia's declaration of independence in 1991. Slovenian society is still inclined to having the urban space open for everyone, except for the clearly delineated private space. At the same time, private owners are increasingly organising the limits of their private space.

2. Such a high percentage was achieved in development projects with a special emphasis on providing and preserving areas in public use, through Slovenia's own engaged townplanning practice. In most of the case studies, the author of this paper was the responsible designer. The partners in the case study projects achieved relatively successful cooperation - among the public sector, private developers, and the public, which brought high-quality solutions. The criterion for assessing the quality of solutions is an unambiguous one
- PS and PSOP developments and facilities of sufficient scope and quality.

The study showed that the regulations already allow for the development of appropriate shares of PS and (potential) PSOP, and their proper arrangements; however, they do not regulate nor promote the organisation of PSOP. The ratios between the PS, PSOP and PrS areas in individual projects largely depend on private owners' cooperation, activities in the area and the location of the site within the city, the success of project preparation, and similar. There is no guarantee that in similar areas we could in general achieve appropriate shares of PS and PSOP and their quality development. Namely, the provision of PSOP was largely left to the varied circumstances at the local level, the negotiational ability of the municipality or state and spatial planners, and the various requirements of the public and private developers.

Moreover, there is also no guarantee that the organisation of PSOP will be of sufficient quality. "We defined the criteria used to assess the quality of solutions that provide good quality of living" [17]:

- PSs and PSOPs of sufficient scope.

- well accessible PSs and PSOPs. PS open to the public 24 hours a day (except for justified reasons such as user safety). PSOP open to the public at least 12 hours per day (the average working hours of shops).

- good urban facilities and vegetation at PS and PSOP, friendly to users.

- PSOPs well-connected into a public space network [17].

Since in Slovenian urban planning practice there are no guarantees - provisions to achieve appropriate shares of PS and PSOP and an PSOP design of sufficient quality, we designed urban design guidelines to facilitate a systematic and uniform development of PS and PSOP.

\section{PROPOSAL OF URBAN DESIGN GUIDELINES FOR THE ORGANISATION OF PS AND PSOP}

Urban design guidelines for provision of PSOP and for integrated development of PS and PSOP are the result of the study and the parallel assessment of study findings using urban design. They are a tool to ease the elaboration, implementation and more successful introduction of quality PS and PSOP. They define the recommended PS and PSOP ratios, and conditions regarding accessibility and facilities. Urban design guidelines are the principle for organising qualitatively abundant, well accessible and equipped, and programmatically versatile PS and PSOP. At the same time, 
Table 2. Proposal of minimum recommended ratios of PSs and PSOPs [30].

\begin{tabular}{|c|c|}
\hline Recommended Surface Area of PS and PSOP & Recommended Ratio of PS and PSOP \\
\hline \hline PS $\geq 15 \%$ of surface area & JP + JOP $\geq 35 \%$ of surface area \\
\hline JOP $\geq 20 \%$ of surface area & PS: PSOP $=1: \geq 1.2$ \\
\hline
\end{tabular}

the guidelines note the necessity of professionally guided cooperation among the partners.

\section{Proposal of PS and PSOP Ratios}

Based on the identified situation of the scope of public areas in towns and cities, and the scope of potential PSOP in the analysed parts of towns and cities, we drafted a proposal of recommended ratios of PS, PSOP and PrS surface areas. The recommended share of PS is at least $15 \%$ of total area under development, and PSOP at least $20 \%$ of the area (Table 2), depending on the intended land use. The highest shares are recommended for mixed-use areas. According to the analysis, the recommended share of PS and PSOP for these areas is at least $20 \%$ and $25 \%$ of the area, respectively.

\section{Urban Design Guidelines}

The urban design guidelines for organising PS and PSOP were designed as a response to the selected case studies, where the analysis of the situation and the project practice pilot study helped us to recognise the poorly realised potentials for providing PSOP and for integrated development of PS and PSOP. The urban design guidelines were designed as a direct response to the identified needs:

- We must systematically address the quantitatively more abundant and better qualitatively developed PS and PSOP.

- The key framework of the urban space provides public space; PSOP connects to it and complements it.

- There are several situations in towns and cities where PS and PSOP are not adequately organised. Good solutions are encouraged by comparable best practices and theory. The potentially good solutions (as all PSOP areas that we measures are potential PSOPs) are noted by the project practice analysed in the study.

- Some urban situations are typical to such an extent that they can be unified and represented in the form of urban design guidelines as the principle of PS and PSOP development in these situations.

The guidelines were prepared for the following typical spatial situations:

1. Profiles of urban public roads as the possibility for organising and expanding the existing PS network.

2. Profiles of urban public roads as the possibility for organisation of PSOPs connected to the existing PS network.

3. Urban waterfront, shores as a possibility for expanding PS and promoting the development of PSOP connected to the existing PS stream and shoreline network.
4. Degraded areas (e.g. along railway lines, stations, abandoned industrial regions) as a possibility for development and rehabilitation of PS and PSOP.

5. Neighbourhoods without a central area, i.e. a core, as the possibility of arranging the core in the form of PS or PSOP, or as a combination thereof.

6. Large, dead-end, enclosed urban areas (e.g. industrial, enclosed residential areas) as the possibility of providing passage across the areas in the form of PS or PSOP.

For all urban design guidelines it is considered that the actual, more detailed solutions and agreements in line with the urban design guidelines are sought in the framework of public-private partnerships, for each case separately, taking into account the strategic development orientations of the state and the municipality, i.e. the town or city.

For implementing the guidelines in practice we proposed a bonus system (of incentives and benefits for developers) in terms of urban planning (flexible floor area ratios, height of structures, and purpose), procedural, financial, aiding partner cooperation (city administration heads partner cooperation in an established way known in advance by involving public communication experts) and promotion of best practice (publications in the professional literature and online). For each guideline the situation-relevant bonuses are selected from the range of bonuses available.

Here we present two cases of the six criteria designed in the study:

\section{Guideline: Encouraging the Development of PSOPs Along Public Roads}

On the outskirts of urban public spaces the developers and owners must be encouraged to promote developments to improve or provide new PSOPs. Land allowing for the expansion of public space for important public roads and paths is particularly important (arcades, passages, private squares, plazas, etc., as the expansion of the street space).

The implementation of the guideline causes the expansion of the PS's scope and the street's profile. This is done in parallel to encouraging the PSOP development. The graphical representation of the guideline (Fig. 6) shows the development of PSOP along a public road with a too narrow public space. In exchange for development the bonus allows for a higher floor area ratio, as shown with arrows [30].

\section{Guideline: Development, Rehabilitation of PS or PSOP in Degraded Areas}

On the outskirts of urban public space, in brownfield areas (e.g. along the railway and on abandoned industrial 


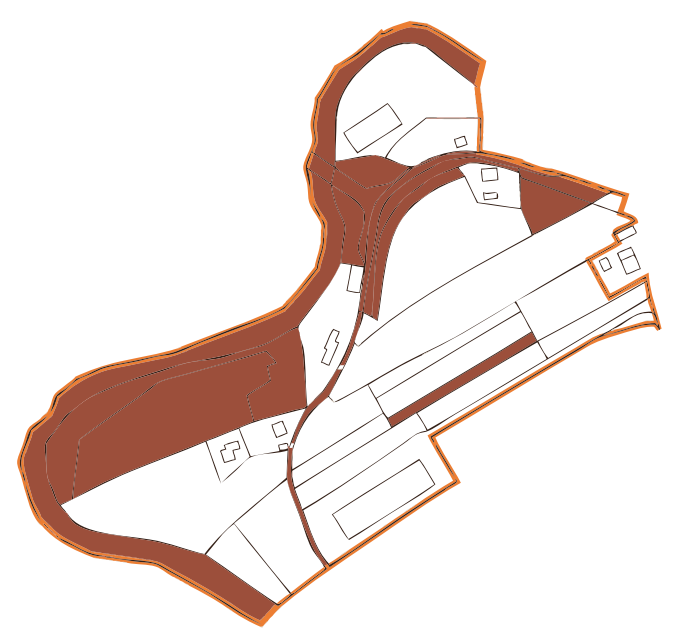

Legend:

PS

(a)
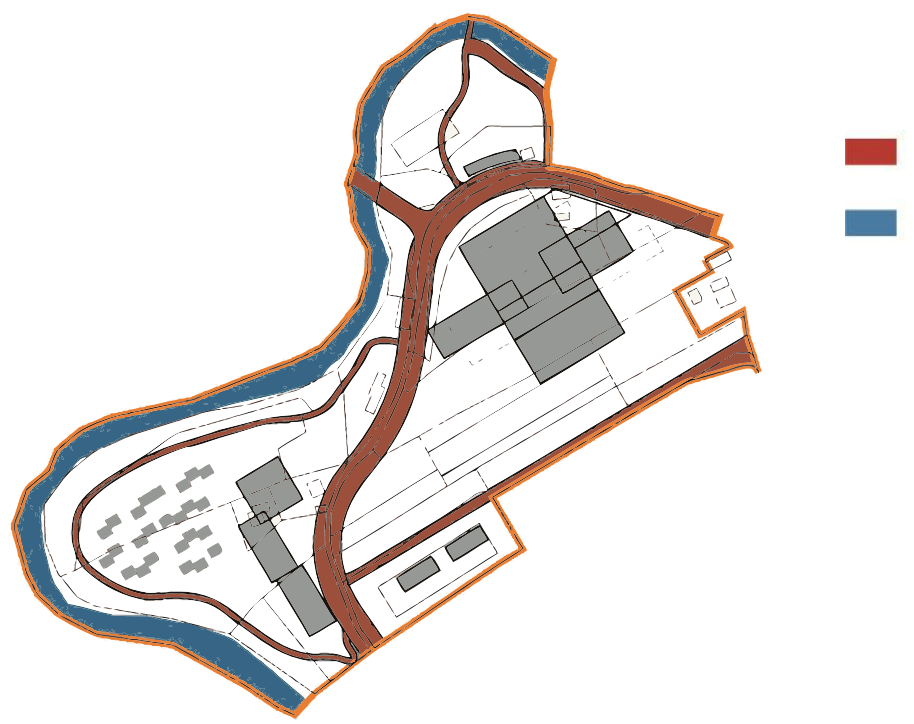

PS - roads

PS - water bodies

(b)
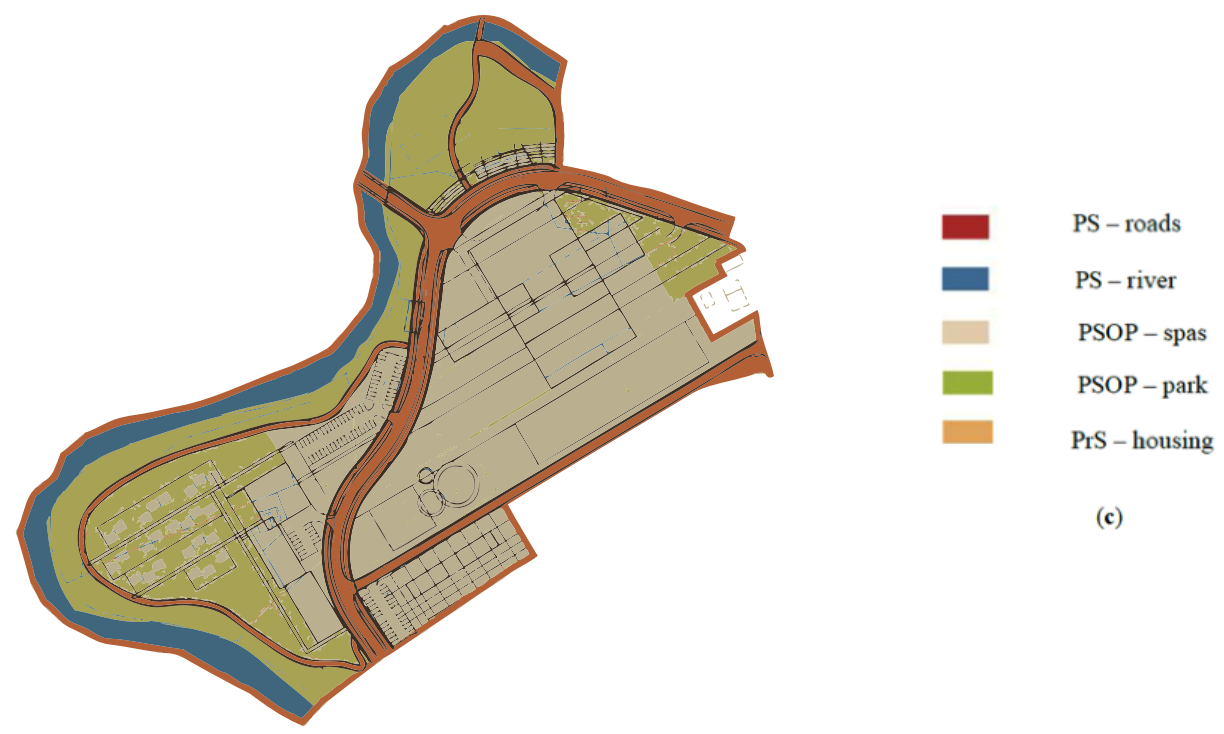

(c)

Fig. (5). "Subdivision of public and private areas at the location studied a) before the preparation of the building plan; b) after the building plan entered into force; $\mathbf{c}$ ) after the building plan entered into force, with simulated PSOP areas" [17], with $15 \%$ PS; $58 \%$ PSOP, and $27 \%$ PrS (notes: $\mathrm{PS}=$ public space, $\mathrm{PSOP}=$ private space open to the public, $\mathrm{PrS}=$ private space). 

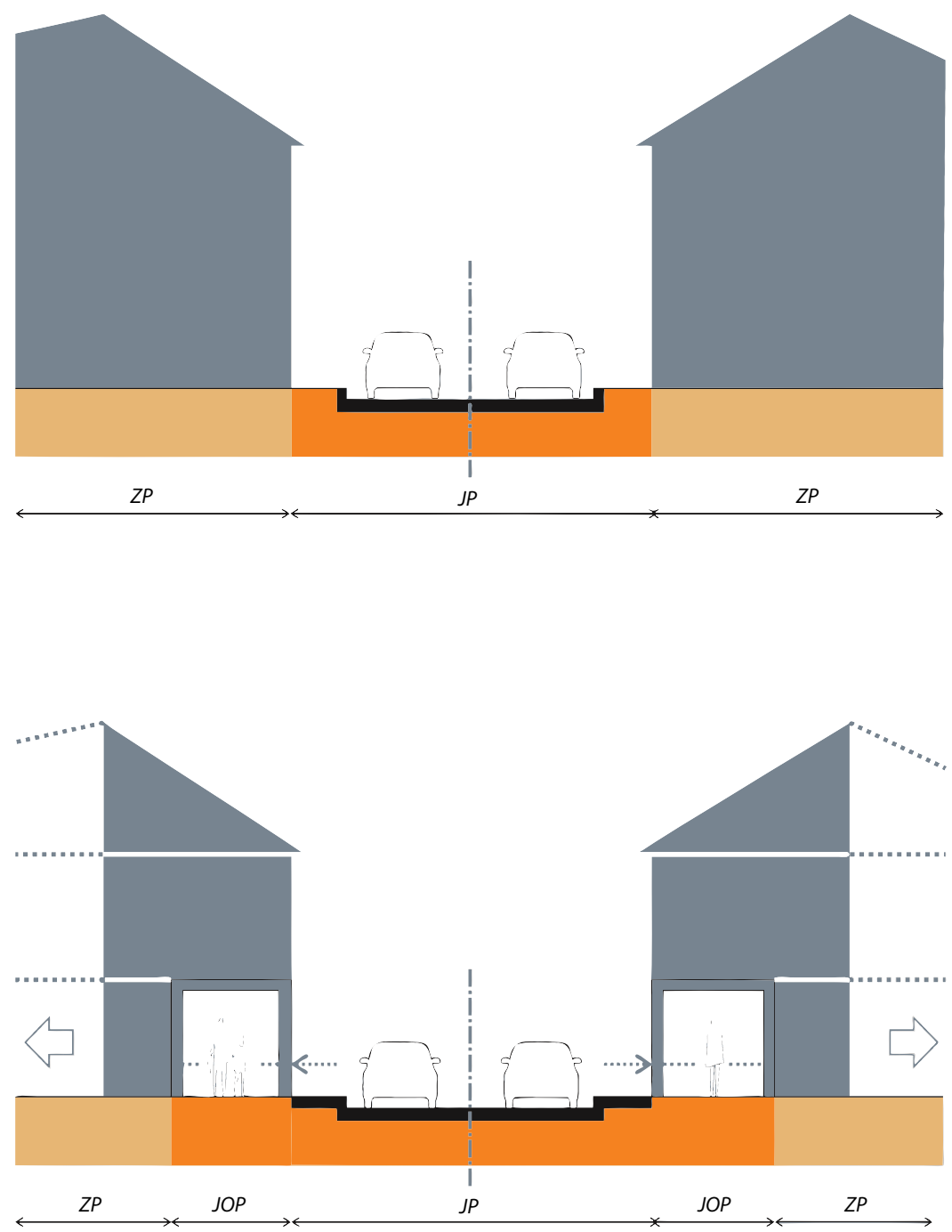

Fig. (6). Promoting the expansion of public space (PS) or the organisation of private space open to the public (PSOP) along public roads. Above - the situation (the thick black line shows the existing width of the PS); below - the recommendation (the thick black line shows the new, expanded PS).

areas) developers and owners must be encouraged to organise and rehabilitate PS and PSOP.

The implementation of the guideline increases the scope of SP, provides public passageways, squares, etc. The development of PSOP is also promoted. A graphical representation of the guideline (Fig. 7) shows the rehabilitation of PS or PSOP in a degraded area In exchange for development the bonus allows for a higher floor area ratio, flexible intended use, and other benefits [30].

\section{DISCUSSION - WHAT CAN BE IMMEDIATELY ACHIEVED?}

"Based on the finding that the provision of PSOP is not established in Slovenian urban-planning practice, a proposal was presented at the end of the study to arrange PS and PSOP in a planned and uniform way. To this end, urban design guidelines for arranging PS and PSOP were prepared; they define the recommended PS and PSOP percentages, their accessibility, infrastructure and activities as well as incentives and benefits that make it easier to implement the guidelines" [17]. The guidelines were complemented by graphical representations showing possible urban-planning solutions under typical circumstances with a recognized potential for organisation of PS and PSOP. "For example, the expansion and development of PS and PSOP was proposed along public roads, watercourses and coasts, in degraded areas, neighbourhood centres, and closed urban areas, i.e. blocks" [17]. Based on the findings that the provision of PSOP is not defined in the legislation governing the preparation of spatial planning and implementing documents, stepwise measures were proposed at the end of the study [17]. PSOP should be clearly defined as a special spatial category $[19,31]$, which is neither PS nor PSOP. PSOP should become a mandatory component of the land subdivision plan when drafting implementation plans such as town-planning schemes.

In substantiating the necessity and prudence of the planned arrangement of PSOP, one can use the provisions of the Spatial Order of Slovenia [32], which stipulates that, "in order to provide the conditions for a healthy life, socializing 

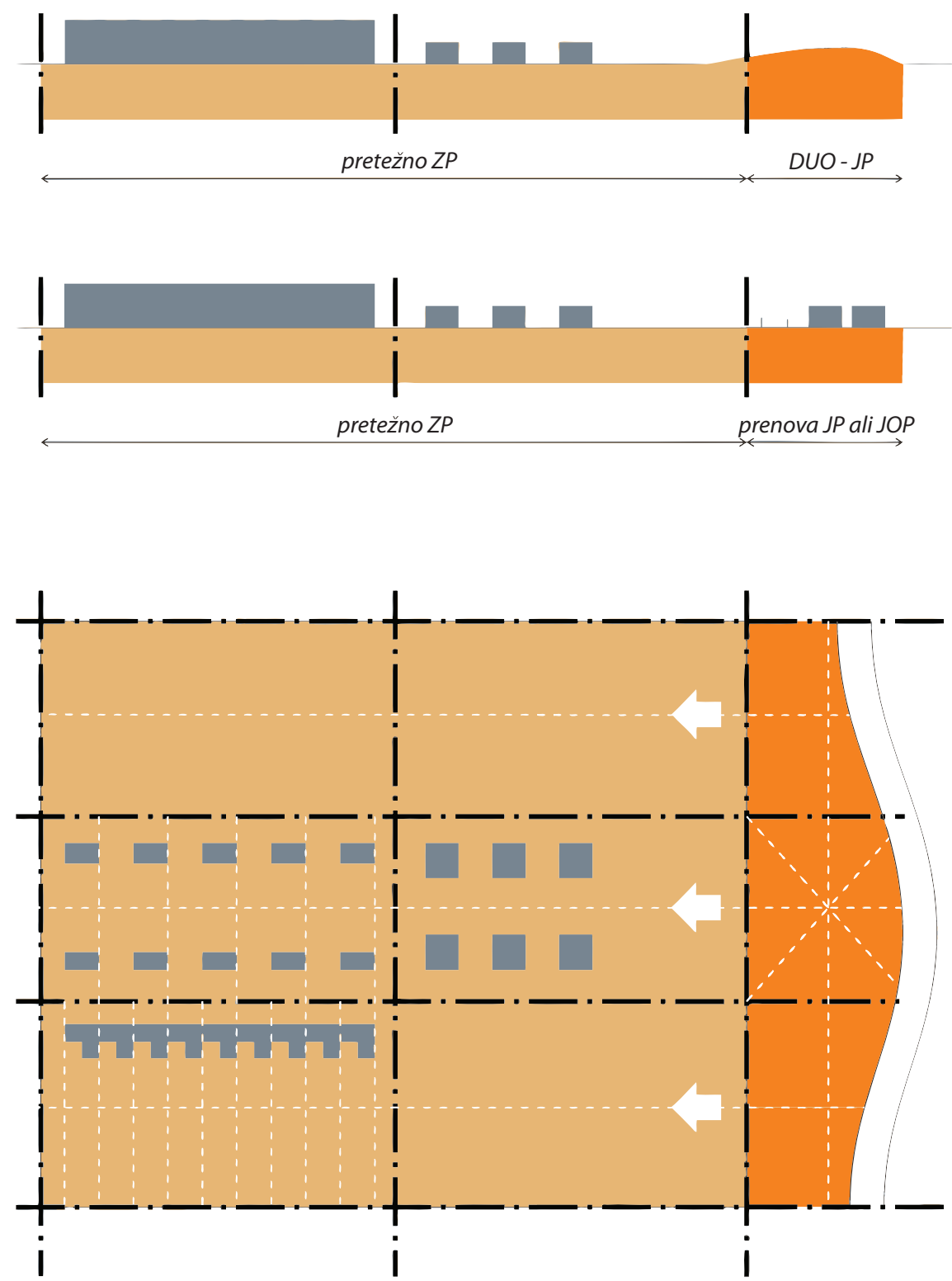

Fig. (7). Development, rehabilitation of public space (PS) or private space open to the public (PSOP) in degraded areas. Above - the situation; the middle and below - the recommendation (the arrows show the expansion of PS and PSOP).

and recreation, "appropriate distribution, functional and structural diversity and quality design of green areas and other open public spaces must be ensured, while taking into account the size of the settlement area and its importance in wider space". In addition, the spatial order stipulates that spaces in front of public structures should be designed as PSs with expressed identity, and spaces in front of large shopping centres as open PSs of urban and regional importance, where recreational, entertainment and cultural activities can be organized [17].

To summarise, an extensive Slovenian PSOP network is already in place: the mountain trail system. This proves that PSOP in Slovenia can be organised with high quality and at the same time it must be legally regulated; the latter is demonstrated by the Mountain Paths Act [20] which regulates the status of mountain trails. In addition, there are many best-practice examples from abroad such as PSOP in New York [19, 33], San Francisco, and elsewhere.

Many European researchers also study PSOP, but many of them simply categorize it under PS because of its public use. According to Ute Angelika Lehrer [34], PS is divided into physical, social and symbolic public space. Physical PS is the most obvious among these and is defined by public ownership. Social public space is created through activities. Social public space creates people's activities and their collective memory (spaces of memories and imagination). In line with such a division, PS is all the space in public use. Ali Madanipour [35] draws attention to setting boundaries 
between public and private spheres. He believes that shaping a boundary between the public and private as a combination of a clear, but permeable division presents a special challenge for developing and building cities. However, only those divisions between the public and private make sense in which both spheres prosper and develop. Jan Gehl [36] emphasizes activities in PS and divides them into necessary (e.g. going to school or to work), optional (taking a walk, sitting in a park, and similar), and social (meeting people, conversations) [37]. Furthermore, PSOP is where mostly optional social activities take place [17].

\section{CONCLUSION}

"The main motivation for studying PS and PSOP was the fact that PS's quantity and quality are limited by ownership conditions and the public sector's financial frameworks. We also established that the cadastral and ownership status of publicly-owned land in Slovenia is often unregulated. For that reason, many public areas are disorganized and poorly maintained. Further motivation for studying and seeking solutions was the fact that PSOPs are characterized by private ownership, private investment and new, private ideas. Because PSOP is not defined as a separate spatial category in Slovenia and because it is not promoted by best practice or regulations, it does not yield such good results as can be seen from the reference best-practice examples from abroad (New York, San Francisco, Hong Kong, and others)" [17].

The pilot study of the project practice confirmed that (potential) PSOP can already be provided now as part of current legislation, based on expert recommendations and best-practice promotion. The project practice example and the average results of the seven project practice cases revealed relatively favourable percentages of PS and PSOP areas. The cases analysed achieved good results with regard to organising PS and (potential) PSOP in terms of their percentage and accessibility. We found that this was the result of the impacts of the former socialist socioeconomic system characterised by the great scope of areas in public use. However, this required a great deal of effort, negotiations and specific conditions in city administration and on site, and similar. It is urgent to introduce PSOP into urban-planning practice as well as to gradually introduce it into regulations.

In the proposal for a more systematic organisation of private land open to the public we should relate to the case of the diversified mountain trail network. The mountain trail network is regulated by legislation and is well organised in the field and massively used. However, the network is traditional. Most of the developments originate from the former socialist socioeconomic system (from the Yugoslavian period before Slovenia's independence in 1991), which were by way of legislation adequately translated into the new conditions. For the cities, where the conflict of interest is the greatest, we should establish a similarly transparent and clear system which will also have to be based on regulations, either at the state level (laws, urban design guidelines as part of the spatial order), or at the city level, as town-planning regulations, as was done in some American cities.

\section{CONFLICT OF INTEREST}

The funding sources had no involvement in conducting the research and preparing the manuscript of this paper.

\section{ACKNOWLEDGEMENTS}

The paper presents a study carried out between 2007 and 2011 as part of PhD studies at the Faculty of Architecture of the University of Ljubljana, which was complemented by practical experience.

\section{REFERENCES}

[1] Jankovič G. L. Private space open to the public as an addition to the urban public space network. Urbani izziv 2012; 23(1): 101.

[2] Bruntland G, Ed. Our common future. Oxford, The World Commission on Environment and Development. Oxford: Oxford University Press 1987: p. 51.

[3] Šarec A, Ed. Agenda habitat, Carigrajska deklaracija, Deklaracija svetovnega zbora mest in lokalnih uprav. Ljubljana, Ministrstvo za okolje in prostor, Urad Republike Slovenije za prostorsko planiranje 1996.

[4] Yau Y. Sense of community and homeowner participation in housing management: study of Hong Kong. Urbani izziv 2010; 21(1): 126-35.

[5] Rogers R. Towards an urban renaissance: Final report of the urban task force. London: E \& FN Spon 1999.

[6] Council of Europe. Conference of Ministers Responsible for Regional Planning, Guiding principles for Sustainable Spatial Development of the European Continent. Hanover 2000.

[7] Ustava Republike Slovenije. Uradni list Republike Slovenije no. 33/1991: 72. člen. Ljubljana.

[8] Ustava Republike Slovenije, Uradni list Republike Slovenije no. 33/1991: 33. člen. Ljubljana.

[9] Zakon o prostorskem načrtovanju, Uradni list Republike Slovenije no. 33/2007, 108/2009: 3. člen. Ljubljana.

[10] Goličnik B. Parks and their users. Urbani izziv 2008; 19(2): 133-9.

[11] Fernandez P A, Arpa X. The public chance: new urban landscapes. Vitoria-Gasteiz: A+t edicions 2008.

[12] Gligorijević Ž, Ed. Uvodne napomene. Javno dobro: indentifikacija, upotreba, upravljanje, dizajn, Beograd, Centar za Planiranje Urbanog Razvoja 2004; p. 2.

[13] Zakon o graditvi objektov. Uradni list Republike Slovenije no. 102/2004. Ljubljana.

[14] Mušič VB. Soodvisnosti regionalnega in urbanističnega planiranja v regionalnem razvoju Slovenije. Dela 2005; 24: 137-46.

[15] Černe T. Informacijski sistem za podporo gospodarjenju z javnimi zelenimi površinami v urbanem okolju. Master's dissertation. Ljubljana: University of Ljubljana, Faculty of Civil and Geodetic Engineering 2009.

[16] Nikšič M. The dimensions of urban public space in the user's mental image. Urbani izziv 2006; 17(1-2): 200-4.

[17] Jankovič GL. Private space open to the public as an addition to the urban public space network. Urbani izziv 2012; 23(1): 101-11.

[18] Robbins E. Rethinking public space: A new lexicon for design. Urbani izziv 2008; 19(2): 140-6.

[19] Kayden J. Privately owned public space: The New York city experience. New York: John Wiley \& Sons 2000.

[20] Zakon o planinskih poteh. Uradni list Republike Slovenije no. 61/2007. Ljubljana.

[21] Németh J. Defining a public: The management of privately owned public space. Urban Stud 2009; 46(11): 2463-90.

[22] Schmidt S, Németh J, Botsford E. The evolution of privately owned public spaces in New York City. Urban Des Int 2011; 16 270-84.

[23] Department of City Planning. City of New York. Privately Owned Public Spaces. [Retrieved Nov 22 2014]. Available from: http://www.nyc.gov/html/dcp/html/priv/priv.shtml 
[24] Seattle City Council. Privately Owned Public Open Spaces (POPOS). [Retrieved Nov 22 2014]. Available from: http://www.seattle.gov/council/licata/public_space.htm

[25] Jacobs F. Sense of POPOS: Secret spaces of San Francisco. Big Think, 27. 1. 2010. [Retrieved Oct 30 2011]. Available from: http://bigthink.com

[26] City of Chicago. Open Space Section. Retrieved 2014 Nov 22. Available from: http://www.cityofchicago.org/city/en/depts/dcd/supp_info/open_space 0 .html

[27] O'Neill B. Pittsburgh Post-Gazette. Public merits a cozy spot among private properties. 12. 8. 2012. [Retrieved Nov 22 2014]. Available from: http://www.post-gazette.com/opinion/brianoneill/2012/08/12/Public-merits-a-cozy-spot-among-privateproperties/stories/201208120170

[28] Rahi G, Martynkiw A, Hein E. Accessing Vancouver's privately owned public spaces. Trail Six: Undergrad J Geog 2012; 6: 24-38.

[29] Luk W L. Privately owned public space in Hong Kong and New York: The urban and spatial influence of the policy. $4^{\text {th }}$ International Conference of the International Forum on Urbanism. Amsterdam, Netherlands, 2009.
[30] Jankovič GL. Javni in za javnost odprti prostori sodobnega mesta. $\mathrm{PhD}$ Thesis. University of Ljubljana, Faculty for Architecture 2011.

[31] Shafer SA framework for creating and using maps of privately owned spaces. Location and context awareness. Lect Notes Comp Sci 2009; 5561: 174-91.

[32] Prostorski red Slovenije. Uradni list Republike Slovenije, no.122/2004; 14706.

[33] Foderaro L W. Privately owned park, open to the public, may make its own rules. The New York Times, 13. 10. 2011. Retrieved 2011 Oct 30. Available from: http://www.nytimes.com

[34] Lehrer UA. Ali je javni prostor še prostor? Mesta, ki se globalizirajo, in privatizacija javnega. In: Čerpes, I and Dešman M (eds.): O urbanizmu. Kaj se dogaja s sodobnim mestom?, Ljubljana, Krtina, 2007; pp. 211-20.

[35] Madanipour A. Public and private spaces of the city. London: Routledge 2003.

[36] Gehl J. Life between buildings: Using public space. København: The Danish Architectural Press 2006.

[37] Gehl J, Matan A. Two perspectives on public spaces. Build Res Inf 2009; 37(1): 106-9.

(C) Liljana J. Grobelšek; Licensee Bentham Open.

This is an open access article licensed under the terms of the Creative Commons Attribution-Non-Commercial 4.0 International Public License (CC BY-NC 4.0) (https://creativecommons.org/licenses/by-nc/4.0/legalcode), which permits unrestricted, non-commercial use, distribution and reproduction in any medium, provided the work is properly cited. 